Research papers

\title{
Callovian (Middle Jurassic) dinoflagellate cysts from the Algarve Basin, southern Portugal
}

\author{
Marisa E.N. Borges ${ }^{\text {a,b }}$, James B. Riding ${ }^{\text {c,* }}$, Paulo Fernandes ${ }^{\text {a }}$, Vasco Matos ${ }^{\text {a }}$, Zélia Pereira ${ }^{\text {b }}$ \\ a CIMA - Centro de Investigação Marinha e Ambiental, Universidade do Algarve, Campus de Gambelas, 8005-139 Faro, Portugal \\ ${ }^{\mathrm{b}}$ LNEG-LGM, Rua da Amieira, 4465-965 S. Mamede Infesta, Portugal \\ c British Geological Survey, Kingsley Dunham Centre, Keyworth, Nottingham NG12 5GG, UK
}

\section{A R T I C L E I N F O}

\section{Article history:}

Received 16 June 2011

Received in revised form 19 September 2011

Accepted 11 October 2011

Available online 20 October 2011

\section{Keywords:}

palynology

biostratigraphy

provincialism

Middle Jurassic (Callovian)

Algarve Basin

Portugal

\begin{abstract}
A B S T R A C T
The palynology of three Callovian (Middle Jurassic) limestone-marl successions from the Algarve Basin in southern Portugal was studied. These localities are Baleeira Harbour, Mareta Beach and Telheiro Quarry; they provide a composite. succession, tied to ammonite zones, through the Lower, Middle and Upper Callovian from the western and eastern subbasins of the Algarve Basin. The three sections generally yielded relatively abundant marine and continental palynofloras. Diversity is low to moderate and the dinoflagellate cyst associations are dominated by Ctenidodinium spp., the Ellipsoidictyum/Valensiella group, Gonyaulacysta jurassica subsp. adecta, Korystocysta spp., Meiourogonyaulax spp., Pareodinia ceratophora, Sentusidinium spp., Surculosphaeridium? vestitum and Systematophora spp. Some intra-Callovian marker bioevents were recorded; these include the range bases of Ctenidodinium ornatum, Gonyaulacysta eisenackii, Korystocysta pachyderma, Mendicodinium groenlandicum, Rigaudella spp. and Surculosphaeridium? vestitum. The occurrences of Endoscrinium acroferum and Impletosphaeridium varispinosum in the Early to Middle Callovian of Mareta Beach and Telheiro Quarry are also characteristic of this interval. At Baleeira Harbour, the presence of Ctenidodinium continuum and Gonyaulacysta centriconnata in the Peltoceras athleta Zone confirms the Late Callovian age of this section. The successions studied were deposited in restricted infralittoral neritic marine environments which lack deep water circulation, and possibly represent restricted embayments. The relatively low diversity nature of the dinoflagellate cyst assemblages appears to be largely due to the highly enclosed nature of this depocentre. Many Callovian index dinoflagellate cyst taxa which are found in northwest Europe are absent in the Algarve Basin. These forms may have been intolerant of enclosed palaeoenvironments which have restricted or no deep circulation. The Callovian marine palynofloras from the Algarve Basin compare well to the few other published records from the Iberian Peninsula of this age. However they are significantly less diverse than coeval floras from elsewhere in the extensive Mid Latitude Callovian phytoprovince. Many typically Callovian dinoflagellate cysts are cosmopolitan, however some provincialism is clearly manifested. The Arctic and Austral Callovian phytoprovinces are characterised by key endemic taxa such as Paragonyaulacysta retiphragmata and Ternia balmei, which are not present in the Algarve Basin and are assumed to have been polar forms.
\end{abstract}

(c) 2011 Published by Elsevier B.V. All rights reserved.

\section{Introduction}

The Jurassic palynology of the Algarve Basin (Fig. 1) in southern Portugal has not been extensively studied. However the Pliensbachian to Kimmeridgian palynology of the Western Subbasin and the Carrapateira outlier was recently summarised by Borges et al. (2011), who also briefly reviewed previous research. The present contribution is a study of the Callovian (Middle Jurassic) palynology of the Algarve Basin based on three reference sections cropping out

\footnotetext{
* Corresponding author. Tel.: + 441159363447.

E-mail addresses: marisa.borges@Ineg.pt (M.E.N. Borges), jbri@bgs.ac.uk (J.B. Riding), pfernandes@ualg.pt (P. Fernandes), vgmatos@ualg.pt (V. Matos), zelia.pereira@lneg.pt (Z. Pereira).
}

in the west and the east of this depocentre. These successions are Baleeira Harbour, Mareta Beach and Telheiro Quarry (Fig. 2); all three have ammonite zonal control (Figs. 3-5). These localities provide a representative west-east transect through the entire Callovian of the Algarve Basin. Borges et al. (2011) included a preliminary study of the Callovian palynology of Mareta Beach.

In comparison to the Iberian Peninsula, the Callovian palynology of northwest and eastern Europe has been relatively well studied. Principal contributions include Woollam (1980), Berger (1986), Riding (1987, 2005), Prauss (1989), Dodekova (1990), Riding and Thomas (1997), Poulsen (1998) and Riding et al. (1999). In contrast, there are very few contributions on the Middle Jurassic palynology of southern Europe (Borges et al., 2011; Smelror and Leereveld, 1989; Smelror et al., 1991). This study aims to 